Egyptian Journal of Aquatic Biology \& Fisheries

Zoology Department, Faculty of Science,

Ain Shams University, Cairo, Egypt.

ISSN $1110-6131$

Vol. 24(1): 161 - 172 (2020)

www.ejabf.journals.ekb.eg

\title{
The Relationship between Algal Counting and Chemicals Consumption of Conventional Purification Systems at Qena Governorate, Egypt
}

\author{
Fathy M. Mohamed ${ }^{1}$, Faten Nasr EI-Deen ${ }^{2}$, and Ahmed M.Kamal ${ }^{2}$ \\ ${ }^{1}$ Faculty of Earth Sciences, Beni- Suef University, Beni- Suef city, Egypt \\ ${ }^{2}$ Qena company for Water and Wastewater, Egypt. \\ * Corresponding author:fathy19730306@gmail.com; fathy1973@esc.bsu.edu.eg
}

\begin{abstract}
ARTICLE INFO
Article History:

Received: Jan. 18, 2020

Accepted: Jan. 29, 2020

Online: Jan. 31, 2020

Keywords:

Coagulation,

flocculation,

Alum,

Chlorine,

Algal count

ABSTRACT

This study is concerned with studying the relationship between algal count (Diatoms, Green algae, Blue green algae), turbidity, $\mathrm{pH}$, temperature, residual aluminum, alum and chlorine dose during one year (2018) at five surface plant intakes (Nag-Hammadi, Dishna, El-Salhyia, Qeft and Qous plants) at Qena governorate. Results show that alum dose had a linear relationship with temperature and turbidity; this indicates that the amount of chemicals and doses increases with increasing algae count in water intakes. In Nag-Hammadi plant the highest alum dose was recorded in January, 2018 whereas the least alum dose was in August, 2018, when the lowest algae count was recorded. So, it is advisable and less cost to study the algal count along one year for the expected intake for any new plant to know the required chemicals that this plant needs in the future. In addition, we have to take into consideration that the seasonal variation in these algal count, affects the chemical dosages required for water treatment.
\end{abstract}

\section{INTRODUCTION}

In Qena Governorate, the daily drinking water production is about $500,000 \mathrm{~m}^{3}$; each one cubic meter consumes about 8-10 g of Alum, which produces 4-5 g of Aluminum hydroxides. The current plants under study considered the main sources of drinking water of Gena Governorate (MOHUUC,2019). There are many types of algae can be grow in the River Nile, due to pollution from the factories and households sewage water.

One of the most important needs of a society is a clean and secure water supply (Uduman et al., 2010). The provision of safe drinking water plays an important role in preventing the incidence of many water transmissible diseases (Shehata et al., 2008). Water is used for drinking after treatment to conform to quality parameters. Due to large amounts of 
nutrients such as nitrogen and phosphorus from both the production and consumption sectors are being discharged into water bodies every year, resulting in water eutrophication becoming an increasingly important problem. Permanent appearance of algae is considered to be an undesirable water pollutant in drinking water resources such as reservoirs and at water and wastewater treatment plants causing odor, taste and other severe health issues (F. Qu et al.,2012). The qualitative and quantitative analysis of phytozooplankton in treatment plants is important, not only for treatment efficiency, but also for monitoring changes in water quality (Uduman et al., 2010). Treatment prior to human consumption depends on the source water quality. At present, many cities that get their main water supply from lakes and rivers are affected by varying degrees of algal pollution (Shen et al., 2011). The presence of algae in source water can cause a variety of problems for drinking water treatment (Henderson et al., 2008). Algae are known to interfere with the water treatment process, causing increases in coagulant demand, and microbial regrowth in distribution systems (Plummer and Edzwald, 2001). Algae are typically removed using the following treatment chain: pre-oxidation, coagulation and flocculation, and clarification either by dissolved air flotation (DAF) or sedimentation, followed by granular media filtration. Direct filtration can also be used as a clarification process (Henderson et al., 2008 and Fast et al., 2014), as well as utilization of ultra filtration (Qu et al., 2012).

Coagulation is the key step in conventional water treatment processes. Chemical coagulation is commonly used in the treatment of water. The effective reduction of clay, silt, organic matter, algae, and bacteria in surface waters by coagulation and settling is demonstrated daily in water works operation. Even though the coagulation of clays and other inorganic sols has been reported in detail, similar attention has not been given to the coagulation of algae (Djamel et al .,2014). Algal extracellular products interfere with the coagulation-flocculation process leading to increased turbidity and impaired disinfection efficiency with chlorine. Algal penetration through filters imparts abnormal taste and odor (Babel et al., 2002). Chemical algae removal methods are considered as costeffective and user-friendly, because the existing workflow would not be significantly changed and there would be no increase in the amount of large-scale equipments and structures. Numerous studies have showed that pretreatment with chemical agents such as chlorine, chlorine dioxide, ozone, or permanganate can enhance algae removal by chemical coagulation processes (Plummer and Edzwald, 2002 and Knappe et al., 2004). The chemical preoxidants are powerful oxidants and can improve algae coagulation by inactivating algal cells, destabilization of algal cells, or liberating extracellular organic matter (EOM). Chlorine acts to kill the algae by first penetrating through the cell wall then destroying enzymes within the cytoplasm (Shen et al., 2011 and Li et al.2016).

Flocculation is the process where a solute particle in a solution forms an aggregate called a floc. Flocculation is the result of collisions between solute particles and the adherence to each other in a suspension (Pieterse and Cloot, 1997). Most microalgal cells 
have a size range between 5 and $50 \mu \mathrm{m}$ (Djamel et al .,2014) and form stable suspensions with negatively charged cellular surfaces. The stability of these microalgal suspensions is dependent on the forces that interact between the cells themselves and between the cells and water. Hence they are considered as hydrophilic bio-colloids which aid in the understanding of the mechanisms of flocculation; namely charge neutralization and polymer bridging (Uduman et al., 2010). The most important factors related to the removal of algae by coagulation appeared to be alum dosage, the initial algae concentration, and the shape and size of the genera encountered (Djamel et al .,2014). The effects of chemical dose (coagulant and coagulant aid) and $\mathrm{pH}$ on the removal of algae count by coagulation were evaluated with jar tests experiments conducted on synthetic waters (Ayşe et al., 2016).

. The amount of chemical required to remove the algae was largely governed by the number and size of the algae present. (Djamel et al .,2014) conducted that algal growth may be controlled with more frequent cleaning of the basins especially in summer periods and coverage of open sedimentation basins would be avoided to benefit from solar radiation disinfection and oxygen diffusion from the air as well as controlled of coagulant addition.Many developing countries can hardly afford the costs of imported chemicals for water and wastewater treatment (Ndabigengesere et al., 1995).Therefore the primary objective of this study is investigating the effect of biological properties of raw water from five surface plants (Nag-Hammadi, Dishna, El-Salhyia, Qeft and Qous plants) especially total algae count on the amount of chemicals consumed by these plants. So it will be possible to expect the chemical cost for treatment in each plant depending on the biological properties of its water source. The effect of these biological properties on raw water turbidity and drinking water residual aluminum was also followed.

\section{MATERIALS AND METHODS}

\subsection{Sampling site description:}

Water samples were collected monthly intervals during one year (2018) from five surface water treatment plants (Nag-Hammadi, Dishna, El-Salhyia, Qeft and Qous). These plants are shown in (Figure 1).

\subsection{Water quality:}

\subsubsection{Physico-chemical characters:}

Temperature, turbidity and $\mathrm{pH}$ of plant intakes samples were determined in the field according to the methods provided by APHA (2005). Then, the collected samples were brought to laboratory and analyzed for total dissolved salts and residual aluminum according to APHA (2005) within 24 hours.

\subsubsection{Algae samples and counting:}

Samples for biological analysis were also brought to laboratory and enumeration of phytoplankton was accomplished according to APHA (2005). Diatoms, green algae, blue 
green algae and total algae were counted on a compound microscope in a SedgewickRafter Counting chamber after preservation in Lugol's iodine. Cell counts were carried out to a minimum precision of $20 \%$.

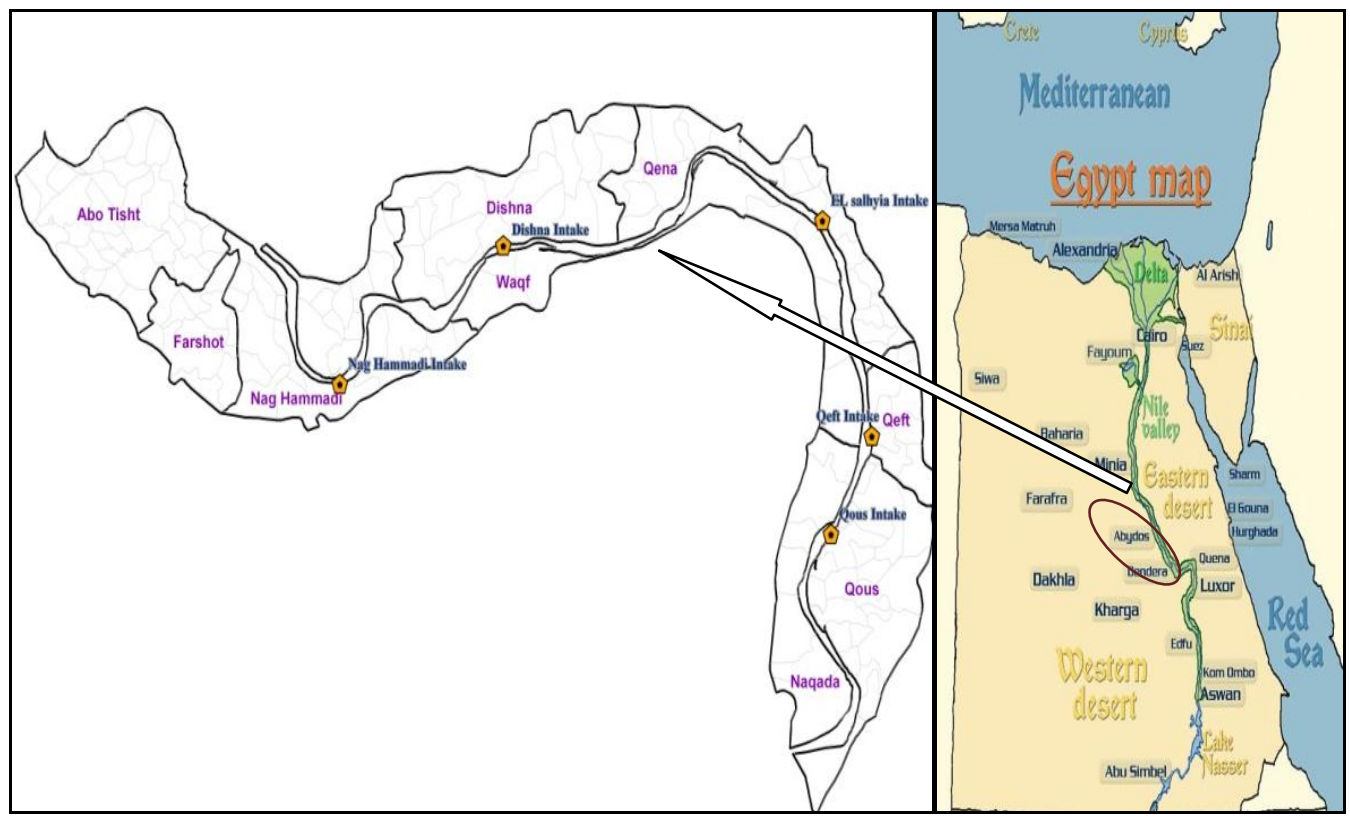

Figure (1): A map of Qena governorate illustrating the five selected of surface plant intakes under investigation.

\subsection{Water treatment processes:}

All the surface plants studied used free chlorine for disinfection and aluminum sulfate for coagulation. Chlorine dosage was determined according to break point test whereas alum dosage was determined according to standard Jar test which was conducted in one-liter beakers to evaluate coagulation efficiencies. Chlorine: Saturated chlorine water solution was used. The power of the available chlorine (concentration) was determined iodometrically (APHA, 2005). Jar Test: Coagulation and flocculation was conducted via the "Jar test" procedure which devised by (David (1993).

\section{RESULTS}

The monthly variation in the physio-chemical and algae count of surface plant water intakes (Figure 1) intakes is presented in Figures (2-9) whereas the correlation between these properties and alum and chlorine dosages is presented in Table (1). The experimental results showed that there is a positive correlation between the algal count of the raw water that feed surface plants and the chemicals used for treatment. For example 
alum and chlorine dosage increased when the turbidity increased in all surface plant water intakes (Figure 2), which was much more pronounced in winter season. Turbidity ranged from 1.5 NTU in summer season to 5.4 NTU in winter season whereas chlorine and alum dosages ranged from 3 to 8 and 7 to $15 \mathrm{mg} \mathrm{l}^{-1}$ for chlorine and alum respectively in the same season. This illustrates that chemical dosage of chlorine and alum doubled when the turbidity increased. Turbidity is often used to quantify suspended particles caused by biotic mass developments, microbial contaminations or tributary inputs (Znachor et al., 2008). High concentrations of particles irrespective of their origin are generally undesired in drinking water reservoirs as they cause economic costs necessitating treatment processes such as sedimentation, flotation and filtration (Scheifhacken et al., 2010). So it can be assumed that there is a positive correlation between water turbidity and chemical consumption. Also it was observed that there is somewhat increase in water turbidity of water samples from north plant intakes (such as Nag-Hammadi intake) when compared to the south plant intakes (such as Qous intake) which had pronounced effect on chemical consumption. This may be due to increasing water pollution as the water run from south to north along the River Nile.

As the hydrolysis products of aluminum coagulants are significantly affected by the $\mathrm{pH}$ of the solution (Lin et al., 2008 and Ayşe et al., 2016), the variation in $\mathrm{pH}$ was also followed. The data in figure (2) showed that there is no significant difference in $\mathrm{pH}$ of water samples collected from the different intakes along one year. $\mathrm{pH}$ of the different water samples was around $\mathrm{pH}=8$ which aid in the coagulation process but did not have a direct effect on chemical consumption. Consistent with the reported results obtained by (Amuda and Amoo, 2007 and Yang et al., 2010), turbidity removal efficiency increased obviously with $\mathrm{pH}$ when initial $\mathrm{pH}$ is lower than 6.0 and could reach about $90.5 \%$ for $\mathrm{Al}_{2}$ $\left(\mathrm{SO}_{4}\right)_{3}$, at the dosage of $10.0 \mathrm{mg} / \mathrm{L}\left(\mathrm{Al}_{2} \mathrm{O}_{3}\right)$ when the initial $\mathrm{pH}$ is between 7.0 and 9.0. The variation in temperature along one year was also detected in the different intake samples and shown in figure (3). The results illustrated that temperature is negatively correlated with alum and chlorine dosage in all water samples collected. When temperature decreased the chemical used for water treatment increased and vice versa. Azeez (2014) suggested that the increase in viscosity at a low temperature might negatively influence the settlement of the flocs. Similar results were also obtained by (Xiao et al. (2009).

The increase in turbidity which was much more pronounced when the temperature decreased may be related to the increase in algal count. The results in Figure 4 and 5 showed variation in algal count of plant intakes. River Nile water showed various phytoplankton structures belonging to three main groups, namely, Chlorophyceae (Green Algae), Cyanophyceae (Blue-Green Algae) and Bacillariophyceae (Diatoms). The highest count of algae was observed in winter season (Dec. to Feb.) whereas the least count was found in the summer season (Jun. to Oug.). The highest numbers were recorded for diatoms followed by green algae and finally for blue green algae. Generally there was a 
positive correlation between turbidity, algae count and the chemical consumption (alum and chlorine) its records that 0.818 and 0.2247 , respectively for algal count and 0.5411 and 0.0262 , respectively (table (1).

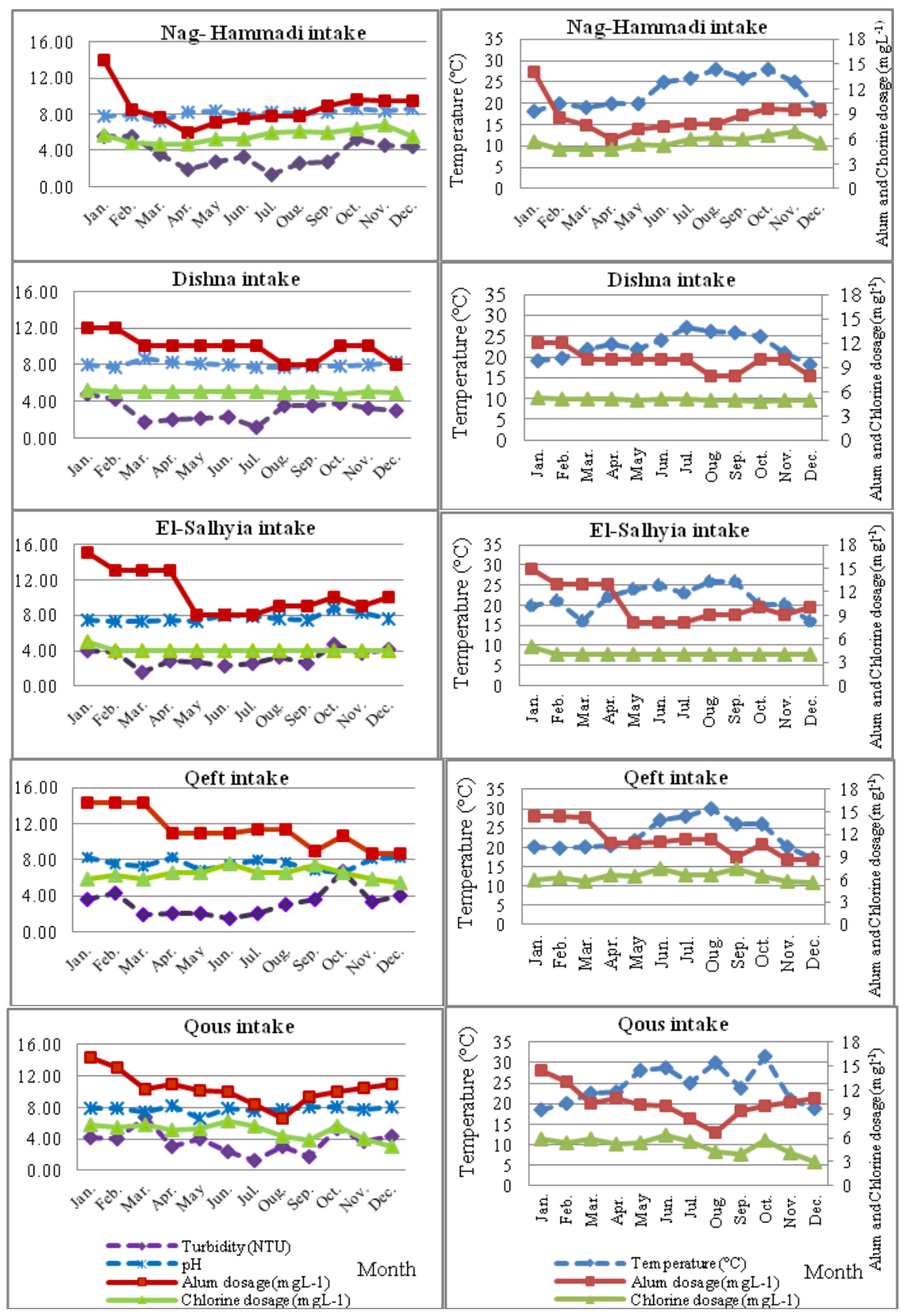

Figure (2): The variation in Figure (3): The variation in temperature, turbidity, $\mathrm{pH}$, alum and chlorine alum and chlorine dosages along one dosages along one year in five year in five surface plant intakes. surface plant intakes. 


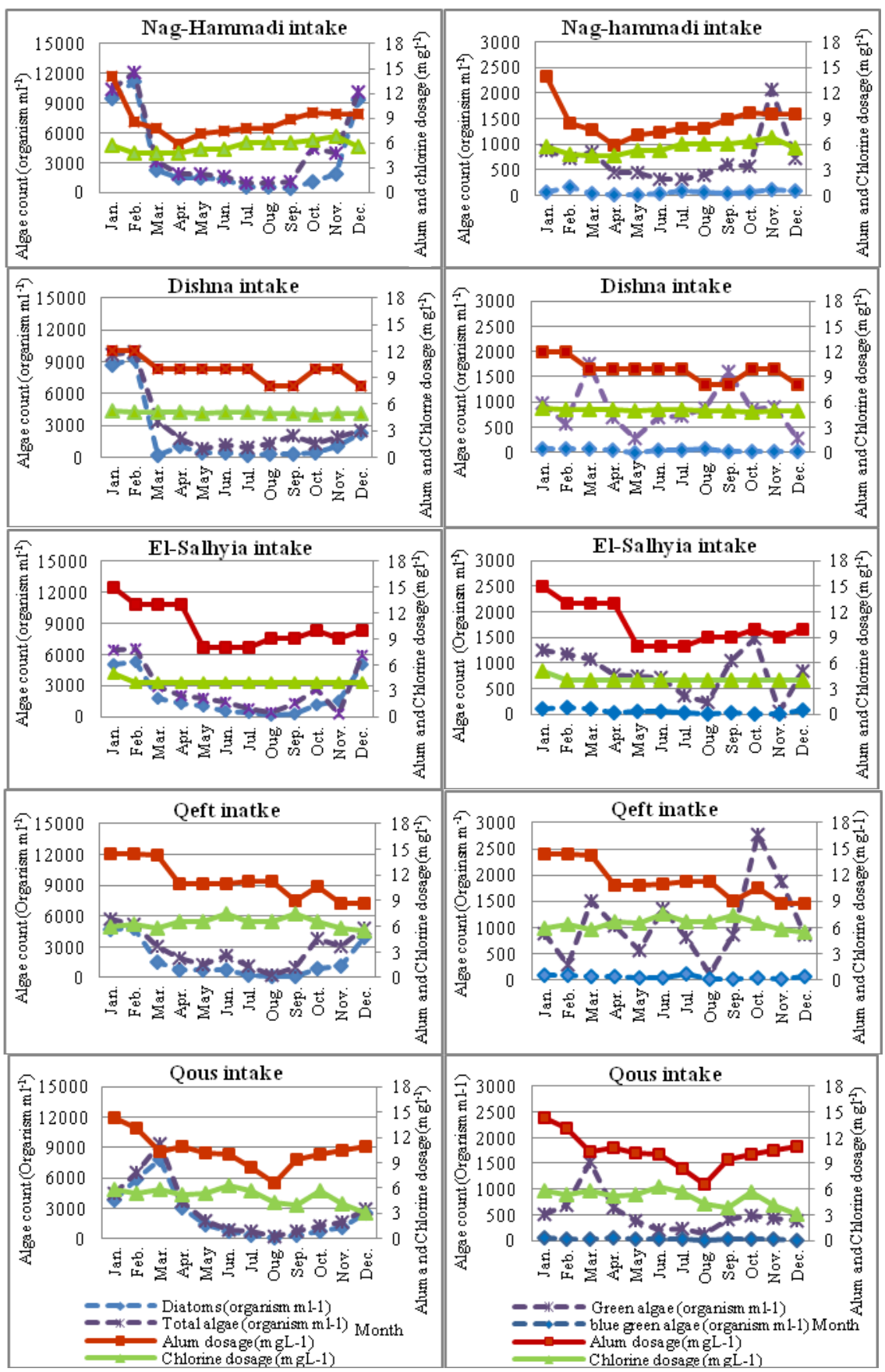

Figure (4): The variation in diatoms, Figure (5): The variation in green, total algae count, alum and chlorine dosages along one year in five surface plant intakes. blue green algae count, alum and chlorine dosages along one year in five surface plant intakes. 


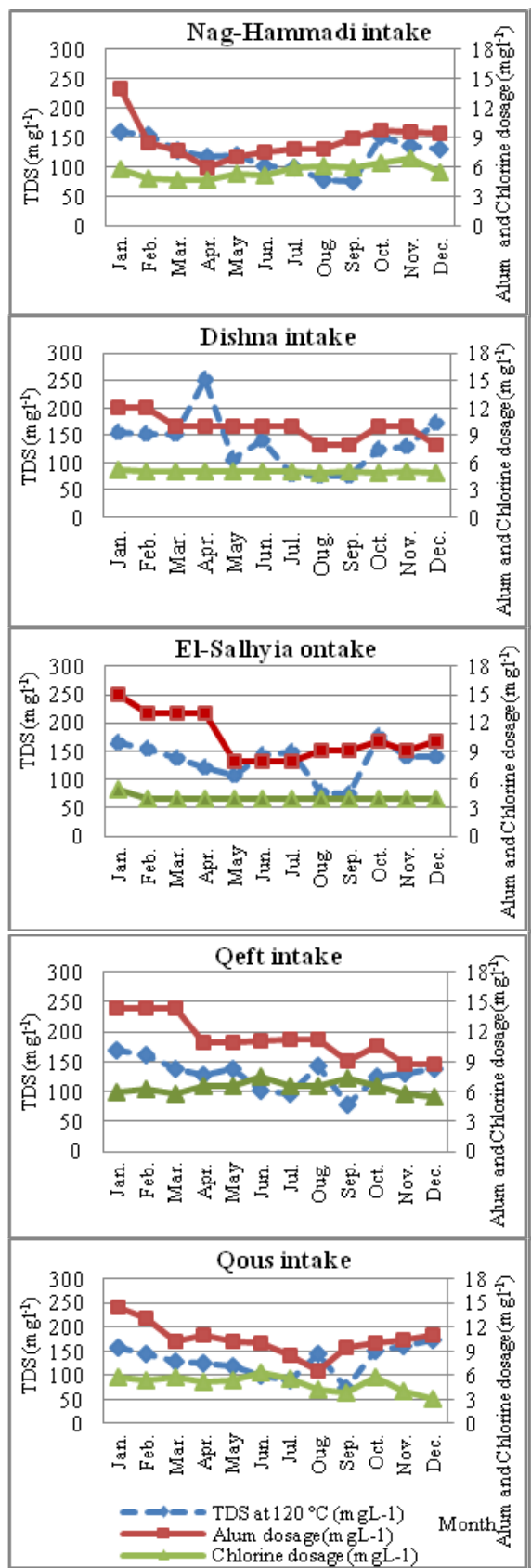

Figure (6): The variation in TDS, alum and chlorine dosages along one year in five surface plant intakes.

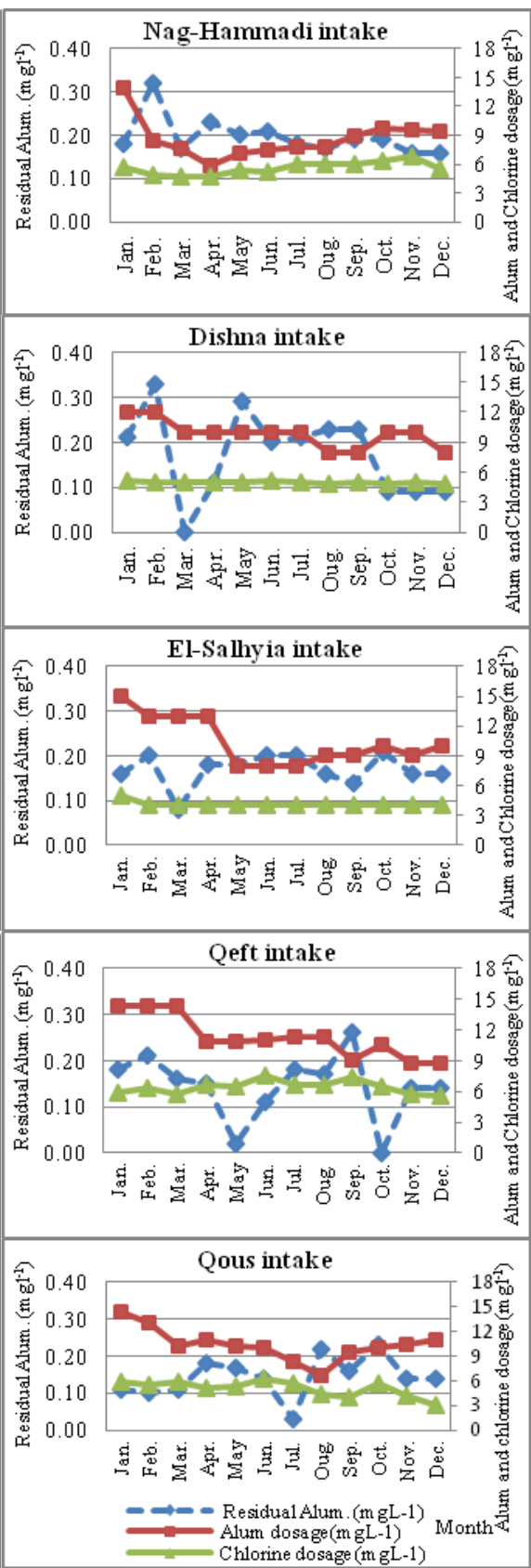

Figure (7): The variation in turbidity, $\mathrm{pH}$, temperature, alum and chlorine dosages along one year in five surface plant intakes.

This increase in chemicals dosage was expected to increase with increasing algae count because algae removal is enhanced mainly by increasing the coagulant and chlorine dosage. The high levels of algae have a cost implication due to the resultant high chemical demand in the different stages of treatment (Hoko and Makado, 2011). The strength of this correlation between algae count and chemicals consumption increased in 
winter season with decreasing of temperature. (Shen et al., 2011) reported that the total algal biomass reaches the highest value when the daily water temperature is between 21 and $24{ }^{\circ} \mathrm{C}$, the concentration of algae cells decreases gradually when the water temperature exceeds $24{ }^{\circ} \mathrm{C}$. Although temperatures for optimum growth of algae differ among algae classes and genera, temperature is one factor that determines the succession of algae in a water body, and the growth rates of algae vary as function of temperature (Knappe et al., 2004). Temperature would influence physiological responses, metabolic rates of algae and the utilized coefficient of nutrients. (Fathy et al., 2019) concluded that optimize the dose of chlorine to be adequate for the killing of water- borne microorganisms and to reduce the high risk from disinfection by-product formation.

The correlation between total dissolved salts (TDS) and alum and chlorine dosage used for treatment was shown in Figure (6). In most samples collected and analyzed, it was observed that when TDS increased the chemical dosages of alum and chlorine increased, so it can be said that generally there is a positive relationship 0.6545 and 0.4230 , respectively, as shown in table (1). This can be explained on the basis that when TDS increased, algae growth increased which resulted in a pronounced increase in water turbidity require more chemical dosages.

Table (1): Correlation matrices of physio-chemical and biological properties determined with alum and chlorine doses

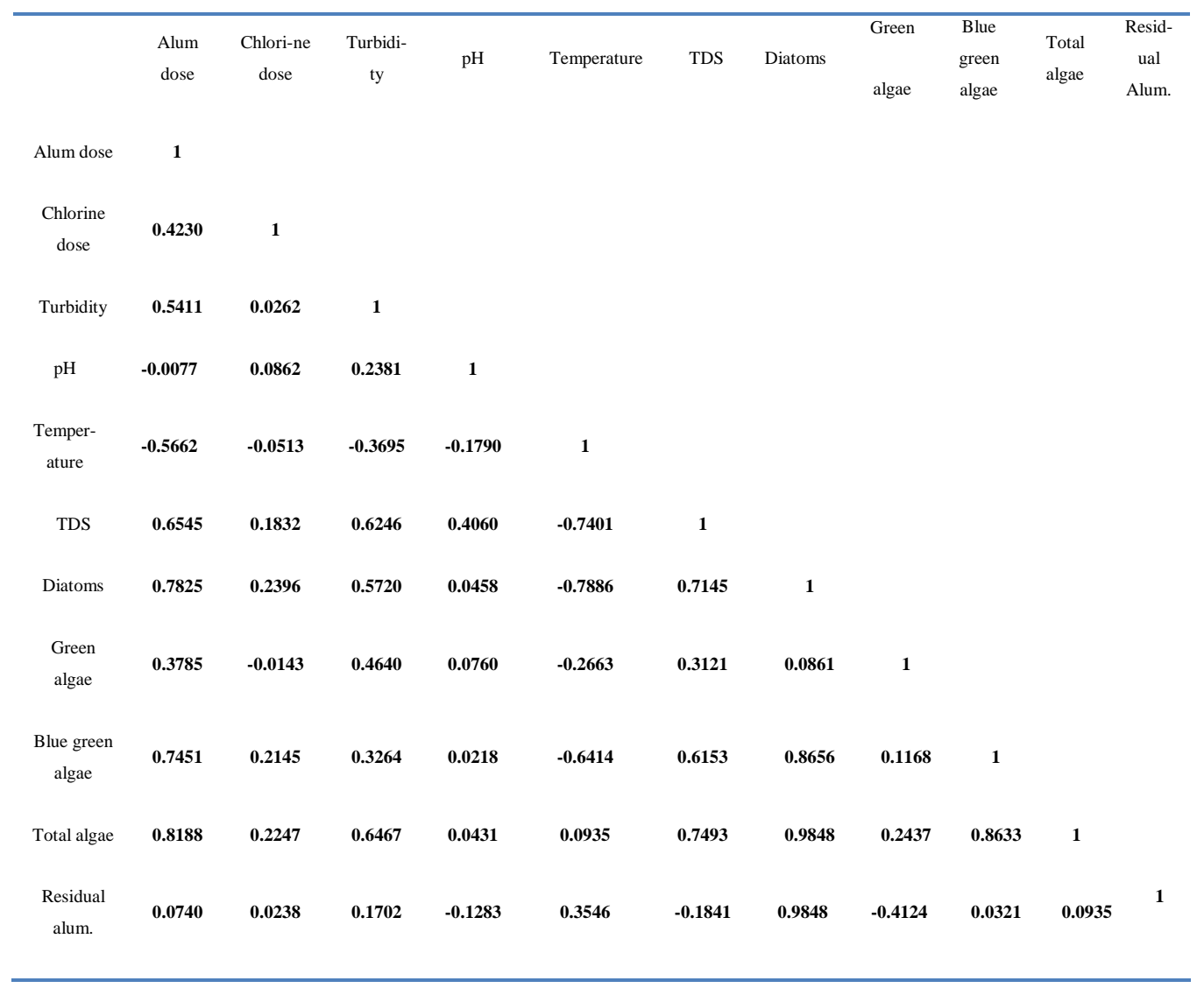


This increase in algae count and turbidity also affects slightly on the concentration of residual alum for drinking water samples which obviously explained in Figure (7).

The results indicated that in most cases there is a good correlation between increasing turbidity, alum dosage and increasing residual alum in drinking water produced, so it can be said that generally there is a positive relationship 0.074 and 0.1702 , respectively, (table (1). But this increase in residual alum in all cases did not exceed the Egyptian standards for drinking water which ensure the maximum removal of turbidity (Henderson et al., 2010).

\section{CONCLUSION}

From all the previous results we can conclude that there is a positive correlation between chemical consumption and turbidity, algal count of plant intakes samples whereas there is a negative correlation between chemical dosages and temperature of the raw water. So, these factors are considered as the most effective factors because the other factors such as TDS did not show clear variation. Accordingly, chemical consumption could be estimated on the basis of algal analysis and turbidity estimation. The chemical cost is doubled two or three times when turbidity or algae count increased. So, it is advisable and less cost to study the algal count along one year for the expected intake for any new plant to know the required chemicals that this plant need in the future. In addition, we have to take into consideration that the seasonal variation in these algal count, affects the chemical dosages required for water treatment.

\section{ACKNOWEDGEMENT}

The authors gratefully to Faculty of Earth Sciences, Beni-Suef University, as well as the Qena Company for water $\&$ wastewater. The authors are grateful to the anonymous referee for a careful checking of the details and for helpful comments that improved this paper

\section{REFERENCES}

Amuda, O.S. and Amoo, I.A. (2007). Coagulation/flocculation process and sludge conditioning in beverage industrial waste water treatment, Journal Hazardous Material, 141: 778-783.

Annual report (2019). Holding company for water and waste water. Ministry of Housing, Utilities and Urban Communities (MOHUUC). Egypt.

APHA. (2005). Standard methods for examination of water and waste water, 21 st ed. American public health association. Washington. 
Ayşe B.; Şengül, N. T. and Sevil A. (2016). The use of alum as coagulant for removing cyanobacterial cells in drinking water, Desalnation and Water Treatment. 57: 2561025616.

Azeez R. (2014). Effect of Temperature on Floc Formation Process Efficiency and Subsequent Removal in Sedimentation Process, Journal of Engineering and Development. 18(4): 1813- 7822.

Babel S.; Takizawa S. and Ozaki H. (2002). Factors affecting seasonal variation of membrane filtration resistance caused by Chlorella algae, Water Research Journal. 36: 1193-1202.

David A.P. (1993). Jar Testing: Getting Started on a Low Budget On Tap, National Environmental Service Center.

Djamel G.; Saad M.; Noureddine A. M.; Mohamed A.; Mohamed W. N. and Ahmed B. (2014). Coagulation and chlorination of NOM and algae in water treatment: A review, International, Journal of Environmental Monitoring and Analysis, 2(3): 23-34

Fast A. S.; Bahareh Kand Veera G. G. (2014). Chitosan enhanced coagulation of algal turbid waters Comparison between rapid mix and ultrasound coagulation methods, Chemical Engineering Journal. 244 403-410.

Fathy M. Mohamed; Faten Nasr El-Deen and Mohamed H. Abdo. (2019). Environmental Hazardous Optimization of Chlorine Disinfectant by- products of Drinking Water: Plants and Distribution System "Case Study, Egypt. Aquat. Biol. Fish. 23(5): 393 403.

Henderson R.; Simon A. and Jefferson B. (2008). The impact of algal properties and preoxidation on solid-liquid separation of algae, Water Research Journal. 42: 1827-1845.

Henderson R.K.; Parsons S.A. and Jefferson B. (2010). The impact of differing cell and algogenic organic matter (AOM) characteristics on the coagulation and flotation of algae, water research. 44: 3617-3624.

Hoko Z. and Makado P.K. (2011). Optimization of algal removal process at Morton Jaffray water works, Harare, Zimbabwe, Physics and Chemistry of the Earth. 36:11411150.

Knappe D.R.U.; Belk C.; Briley D.S.; Gandy S.R.; Rastogi N. and Rike A.H. (2004). Algae detection and removal strategies for drinking water treatment plants, AWWA Research Foundation. Denver, USA.

Li, W.; Wu, R.; Duan, J.; Saint, C. P. and van Leeuwen, J. (2016). Impact of prechlorination on organophosphorus pesticides during drinking water treatment: Removal and transformation to toxic oxon byproducts, Water Research. 105, 1-10.

Lin J.; Huang C., Pan J.R. and Wang D. (2008). Effect of Al (III) speciation on coagulation of highly turbid water, Chemosphere. 72: 189-196.

Ndabigengesere A.; Narasiah K.S. and Talbot B.G. (1995). Active agents and mechanism of coagulation of turbid waters using moringa oleifera, Warter Research. 29(2): 703710 . 
Pieterse A.J.H. and Cloot A.(1997). Algal cells and coagulation, flocculation and sedimentation processes, Water Science Technology. 36 (4):111-118.

Plummer J.D. and Edzwald J.K. (2002). Effects of chlorine and ozone on algae cell properties and removal of algae by coagulation, J. Water SRT -Aqua. 51: 307-318.

Plummer J.D. and Edzwald, J.K.(2001). Effect of ozone on algae as precursors for trihalomethane and haloacetic acid. Environ, Sci. Technol. Journal. 35: 3661-3668.

Qu F H.; Liang, J.; Tian, H.; Yu, Z. and Chen, G. L. (2012). Ultrafiltration (UF) membrane fouling caused by cyanobateria: Fouling effects of cells and extracellular organics matter (EOM), Desalination. 293 :30-37.

Scheifhacken N.; Horn H. and Paul L. (2010). Comparing in situ particle monitoring to microscopic counts of plankton in a drinking water reservoir, Water Research Journal. 44: $3496-3510$.

Shehata S.A.; Ali G.H. and Wahba, S.Z. (2008). Distribution pattern of Nile water algae with reference to its treatability in drinking, Water Journal Applied Sciences Research. 4(6): 722-730.

Shen Q.; Zhu J., Cheng L.; Zhang J.; Zhang Z. and Xu X. (2011). Enhanced algae removal by drinking water treatment of chlorination coupled with coagulation, Desalination. 271: 236-240.

Uduman N.; Qi Y., Danquah, M.K. and Hoadley A.F.A. (2010). Marine microalgae flocculation and focused beam reflectance measurement, Chemical Engineering Journal. 162: 935-940.

Xiao F.; Huang J.H.; Zhang, B. and Cui C. (2009). Effects of low temperature on coagulation kinetics and floc surface morphology using alum. Desalination 237: 201213.

Yang Z.L.; Gao B.Y.; Yue Q.Y. and Wang Y. (2010). Effect of pH on the coagulation performance of Al-based coagulants and residual aluminum speciation during the treatment of humic acid-kaolin synthetic water, Journal of Hazardous Materials. 178: 596-603.

Znachor P.; Zapomelova E.; Rehakova K.; Nedoma J. and Simek, K. (2008). The effect of extreme rainfall on summer succession and vertical distribution of phytoplankton in a lacustrine part of a eutrophic reservoir, Aquatic Sciences. 70: 77-86. 